\title{
Undercover Reporting on Refugees in European Union: Diegetic Narration
}

\author{
Alexandra Milostivaya* \\ North-Caucasus Federal University, Department of Translation Studies, 355009 Pushkin Street 1 Stavropol, Russian Federation
}

\begin{abstract}
The article considers characteristics of telling stories in diegesis on the material of newspaper narrative. The aim of the article is examining communicative and pragmatic parameters of German newspaper reportages under the conditions of transformation of a multi-chronotope paper narrative model with the help of displacement of a communicative act of a narrator and a reader into the temporal and local space of the described characters. As examples of diegetic journalist texts, Shams Ul-Haq's reports are considered that are outstanding specimen of German journalism. The reporter came from Pakistan and settled in Germany. The given reportages were made using the method of undercover observation, when the journalist is disguised as a described character and is a communicator in diegesis. The research makes it possible to conclude that pragmatically meaningful positions in narrative are the chronotope, the voices of the storyteller and the described characters, communicating with recipients. The article confirms the thesis of relevance of speech act synergy for optimization of persuasion in the research report with the help of displacement of the narrator/journalist into the environment of the described characters, where he can start a dialogue with the characters and the reader.
\end{abstract}

\section{Introduction}

The principle of anthropocentrism, defining characteristics of development of human sciences in recent years prioritizes cognitive and communicative aspects of verbal interaction. But communicative activity of the author of the text or narrative is in the focus of interest of journalists. In this article we are going to analyze newspaper narrative constructed in a special way, in which the author, who is simultaneously the narrator, moves into the temporal and local space of the characters he describes, becoming one of them. At the same time, a modification of the multichronotope model of newspaper narrative takes place through transposition of a communicative act between the author of the narrative (including the journalist, who is the narrator) and his reader into the sphere of communicative action of the described actors. This leads to identification of the four communicative continuums possible in the narration: author - reader, character 1 - character 2, author - character, character - reader.

In the traditional narrative theory, this narrative technique is called diegesis. We are going to consider various interpretations of this concept in correlation with various types of positional structure of the author (narrator) with the aim of identifying one that is basic for our analysis of a journalist's activity in the diegetic narrative space.

The narrating Self can be present in the narrative in different degrees. G. Genette [1] assumes only two degrees of this presence, supposing that the narrator cannot be an ordinary bit player; the narrator may be either the main character (auto-diegetic narrator), or an observer and a witness. S. Lanser [2], staying in the framework of Genette's terminology, suggested a more detailed scheme, including a five-step gradation of participation in narration and corresponding distances from getero-diegetic, that is, non-diegetic, a narrator:

1. A narrator who has nothing to do with the story that is being told (not present in it).

2. A witness who has nothing to do with the story that is being told.

3. A witness-protagonist.

4. A minor character.

5. One of the main characters.

6 . The main character (narrator-protagonist).

We believe that this classification is too detailed, that is why it is more suitable for a fiction characteristic, not for a journalist narrative.

M.P. Brandes tells about the existence of three kinds of narrators:

1. Auctorial narrator (third person singular).

2. Personal narrator (first person singular), or an actor of the literary work.

3. Personified narrator (third person singular), defined as "narrator".

From the viewpoint of K.A. Dolinin, we can define the following narrative bodies:

1. An auctorial narrator is not a separate person in the text, either coinciding with the author, or his her opposite.

\footnotetext{
*Corresponding author: xyscha@mail.ru
} 
2. The narrator is not identical with the author, he is a functions of narration and action, and the non-diegetic fictional character (the narrator inside or outside the world narrator does not go beyond the narrative function in his/her of the story characters, in the center or on the periphery of speech activity [6]. This simple binary opposition illustrates the plot) [4].

When these types are put on each other four in this research the only difference is that W. Schmid and combinations are possible, according to K.A. Dolinin: as well as possible our thought process in this research; but Prince do not identify the author with the narrator, which

1. An auctorial narrator who is not opposed to the author can be seen in our case in the characteristic of the journalist and localized outside the plot. as a diegetic narrator.

2. An auctorial narrator who is not opposed to the author

As examples of diegetic journalism, we are going to and localized inside the plot (in the center or on the consider a number of narratives about refugees by Shams periphery). Ul-Haq. Shams Ul-Haq is an outstanding representative of

3. An imaginary narrator opposed to the author outside the plot. German research journalism, that is difficult and dangerous

4. An imaginary narrator opposed to the author inside the plot (in the center or on the periphery) [4].

for a journalist and an analytic genre very common in press,

This researcher thinks that the narrator is alienated from cause-and-effect relationships of the most shocking events, the author being himself an object of imagination, which is and documents, trying to make them unavailable. A just only in the imaginary fabulous space of literary journalist research focuses on comprehensive descriptions communication.

of a resounding and negative phenomenon in the social or

E.V. Paducheva notes that the narrator can be political sphere that is being made taboo by representatives personified, when he is one of the characters of the text, that of government and community. (It is about various crimes, is, belongs to the world of the text, e.g., does something, has facts of incompetence and negligence that are of great at least a minimal biography, maybe, even a name. In other interest for the recipients of newspaper narrative) [9 - 14]. words, he/she is a diagetic narrator, belonging to the world of the text. On the other hand, the narrator can be impersonal, because he/she does not belong to the world of the text [5].

Thus we see, that in this typology the case described above is close to the second type in the classification of M.P. Brandes and K.A. Dolinin and the first type in the classification of E.V. Paducheva, though in these cases the synergy with the author's position is possible only in few cases of autobiographic narration. Besides, the narrative of fiction, and not newspaper narrative, is in the center of attention of these researchers, and in fiction the sociocultural sphere of functioning and generating of the contents gives its special fleur to the structure of narration.

E.A. Goncharova and E.P. Shishkina define two types of texts with egocentric narration:

1. Authorized egocentric texts, that is, the author's depicting of his/her own life (an autobiography, a memoir, an essay or letters), where the pronoun "I" is the linguistic and semantic basis to develop the image of the author, referentially matched with the name that is declared in the initial position of the literary work [6].

2. The fictional and individualized egocentric text, where the imaginary narrative "Self" of the narrating character is distanced from the world that is being portrayed, in the epic and psychological sense, though at the same time it belongs to this world [6]. The texts considered in this article are close to the first one of the two types mentioned above, though they are not identical with it, because the author in them plunges into the space of the character, wearing a fictitious mask, and acts according to its rules.

Among modern concepts of narration, the nearest to the model described above is the dichotomy delineating a diegetic and a non-diegetic narrator. The diegetic narrator appears both in the narration (as its subject) and in the storyline (as an object). The non-diegetic narrator tells us not about himself, as a figure of diegesis, but about other figures [7, 8]. Thus, the diegetic narrator combines the

\section{Material and methods}

The materials of our research are texts of a modern German journalist, Shams Ul-Haq, who describes camps of Muslim refugees in Germany, Austria and Switzerland from the viewpoint of a participant observer. The very person of the reporter is interesting. He came from Pakistan and settled in Germany when he was 15 . Now Shams Ul-Haq is a recognized expert in the sphere of terrorism. He is a journalist in a number of TV channels and in other media ("Die Welt", "Märkische Allgemeine", "Sonntagszeitung", "Frankfurter Neue Presse", "Kölnische Rundschau", "Wiener Zeitung", "Tiroler Zeitung", etc.). So, Shams Ul-Haq has undergone secondary acculturation and got integrated into the German society. The research reports by Shams Ul-Haq analyzed in this article were published in such German, Austrian and international newspapers, as "Welt", "Epochtimes", "HuffPost Deutschland", "Berliner Morgenpost" and "Kurier".

The pragmatic and semantic approach, on which this article is based, implies:

- Synergism of mutual activities of many narrating subjects of newspaper narrative, non-linear sense-producing potential, that surpasses pragmatic influence of each of its separate components;

- Acceptance of the post-classic postulate about features of a studied object being determined by conditions of its existence (discursive milieu of narrative), and ways of discovering these features.

In order to solve these problems a number of methods is used, that supplement each other. Descriptive hermeneutic approach is the main one in the article. Besides, situational and contextual analysis is used that is based on establishing a link of this or that element with the discursive context, in which it is used. 


\section{Results and Discussion}

For his journalist research, Shams Ul-Haq uses the method of undercover observation, being disguised as one of the characters he describes, and thus communicating in diegesis. The genre of journalist research originates from the so-called "muckrakers", who published revelatory articles at the beginning of the XX century. The term "muckraking" was introduced in 1906 by President Theodor Roosevelt, when he called so journalists and writers in his speech. The founder of the method of undercover observation in European research journalism was E. Nordström, who had worked as a maid in a rich family and became the founder of the technic of Wallraffing. She wrote "A Maid Among Maids", a book based on what she had seen. G. Wallraff, a famous German journalist, successfully used this method to collect material for his book "At the Very Bottom", about the life of Turkish workers in Germany, who are exploited by local businessmen. G. Wallraff used undercover observation, disguised as a guest worker, a Turk by the name of Ali Levent. He underwent his second acculturation in the world of Turkish workers. His view of the world became richer because of new knowledge about it. So it was transformed. Information about the "alien" was built into his view of the world and became one of the variants that has existed from the very beginning.

Shams Ul-Haq, an expert in Pakistan terrorism, decided to know for sure, what was happening in refugee camps. He could reach such centers in Germany and Austria, and even in the closed "Camp" in Switzerland. He has also visited camps in Syria, Afghanistan and Turkey, and shared his rich experience.

Let us note that one of distinguishing features of Shams Ul-Haq's works is dominant parameters of narrative journalism, namely:

1. Accurate and objective statement of information.

2. Combination of information and reporting styles with the style of fiction, which can make the reader see deeply the ideational, moral and esthetic contents behind a history of real life.

3. Showing personal life stories, containing real characters, an intriguing situation, emotions and feelings.

4.Clearly expressed viewpoint of the journalist presenting events and participants in individual perspective [15].

Thus, research activity of Shams Ul-Haq represents a special source of information about the events that are described; consequently, it represents a special manifestation of direct sociocultural 'evidentiality' (testimony) that is beginning to be considered as a communicative and pragmatic category in modern linguistic literature [16-20].

Let us analyze Shams Ul-Haq's narrative about refugees from the following positions that mark special characteristics of narrative journalism:

- The chronotope: the scene and the way through the description in time;

- Personal voices of the author, the narrator and the characters;
- The specific way of interaction with the readers through the prism of characteristics of the described topic.

The chronotope: the scene and the way through the description in time. In the narrative under consideration the results of Shams Ul-Haq's research done from summer 2016 in refugee camps of Germany, Austria and Switzerland, are described. The journalist/researcher takes the visual image of the characters he is describing, he dresses the way that is common among them, to stay unrecognized: Einfach einen Tag lang nicht rasiert, alte Klamotten angezogen und schon war ich drinnen (Kurier 11.01.2017). - Once I just didn't shave, put on old clothes and went there. So, Shams Ul-Haq tries to stay unrecognized in his new image, that is, not to be noticeable in diegesis against the background of other characters. In some refugee camps, the reporter had to give fingerprints. He did it several times and was lucky, as nobody ever compared those fingerprints with the ones taken earlier. In a refugee camp Traiskirchen he just climbed over a fence and asked for the status of a refugee.

Personal voices of the author, the narrator and the characters. On the pages of the narrative of his odyssey in the world of refugees in cities of West Germany, Shams UlHaq is at the same time the author, the narrator and one of the characters. As a figure in diegesis, the journalist takes different names. In Eisenhüttenstadt he called himself Raya. In Potsdam he called himself Osman. Getting the status of a refugee in Tempelhof, he wrote in the documents, that his name was Vakar Akhmad. At the border crossing point in Kreuzlingen, Switzerland, he asked for asylum as Jamal. But he always kept the surname Akhmad. Being very common, it does not call attention and suits anybody, be it a Pakistani, an Indian or an Iraqi. German press calls Shams Ul-Haq "Flüchtlingswallraff" for the resemblance of his research technique to that of Günter Wallraff, a classic of role transformation in journalism.

From the position of a diegetic narrator he characterizes different people, whom he had had a chance to meer in refugee shelters: Sie wachen nachts auf, weil Ihnen diese Bilder von Misshandlungen, Mord und Folter nicht mehr aus dem Kopf gehen. Sie haben Angst einzuschlafen, weil Sie fürchten, jemand könnte Ihnen den Kopf abschneiden, nur um an Ihr Mobiltelefon zu kommen, so wie Sie es bereits in einem Lager vor der türkischen Grenze erlebten, als einheimische B:anden die Flüchtlinge ausraubten (HuffPost Deutschland 01.07.2017). They wake up at night, they cannot get rid of dreams about murder and torture. They are afraid of going to sleep, thinking that somebody is going to cut off their heads or steal their mobile telephones. They have already seen this at the Turkish border, when local bands robbed refugees.

Shams Ul-Haq especially criticizes the condition of refugees in Tempelhof camp, Berlin, in the newspaper "Berliner Morgenpost". He writes, "I should not wish such a life to anyone" (Berliner Morgenpost 05.01.2017). The reporter and researcher also tells us what he had seen in that camp: refugees cannot sleep at night because the light is on. Besides, he tells us that their food is not tasty and there have been cases of violence in that place.

Being a diegetic narrattor, Shams Ul-Haq gets personally acquainted with many refugees and describes not only their problems, but also various cases of fraud, 
e.g. multiple registration, to get cash benefits. Thus, in Tempelhof camp a correspondent met a foreigner who had done it many times and sent money to Pakistan. Later he was exposed after all and sent to his native country, but given one more cash benefit for that.

Doing his research among Muslim refugees, Shams Ul-Haq met people who had been radical before coming to the European Union. He met a refugee in Tempelhof who had been photographed with weapons. That refugee told Shams Ul-Haq that he had earlier fought for the jihadist group Al-Nusra-Front (Berliner Morgenpost 05.01.2017).

As the journalist says, extremists had prepared a well elaborated system of recruiting refugees. They see to it that the migrants that are under their influence, stay in Germany, and provide money to bribe those who work in camps. Being in the image of a refugee, Shams Ul-Haq saw cases of bribery among those who worked in a refugee camp in Bremen (Epochtimes 03.03.2017). Those who wanted to receive the status of a refugee as soon as possible had to pay for it. Those who wanted to have a more competent translator had also to pay them money. Some translators extorted money from refugees, notwithstanding the fact that their work was quite wellpaid by the state.

Attempts of the government to evaluate the effectiveness of helping refugees are also in the focus of his narration: Positiv fielen mir dagegen Kindergärten, Sprachschulen und die gute medizinische Versorgung auf, die in Dortmund und anderen Unterkünften inzwischen angeboten werden. Das gab es vor zwei Jahren noch nicht (Epochtimes 27.02.2017). - On the contrary, it seemed to me positive that kindergartens and good language schools appeared, and there was good medical service in Dortmund, and in other refugee camps. It had not been so two years earlier. Shams Ul-Haq (as a journalist and a man, not only as a narrator) confirms the idea that bad conditions in which refugees live make them fall under the influence of terrorists: Dann sprechen sie mit den Flüchtlingen, laden sie zum Essen ein und nehmen sie mit in eine Moschee, die von Salafisten geprägt ist... Die Flüchtlinge kommen so in die falschen Hände (Welt 05.01.2017). Then they speak to refugees and invite them to the mosque where Salafis gather. Refugees fall into the wrong hands. A similar idea slips in some other constitutive parts of the narrative of Shams Ul-Haq under consideration. He writes, in particular, Die Flüchtlingsunterkünfte sind ein Nährboden für Salafisten und Terroristen. Manchmal heißt es ja, dass Deutschland Terroristen importieren würde. Tatsächlich aber züchten wir sie selbst heran (Berliner Morgenpost 05.01.2017). Refugee camps have become a growth medium for Salafis and terrorists. Sometimes they even say that Germany imports terrorists. But in reality it breeds them. This way Shams Ul-Haq calls the attention of the European public to the danger connected with lack of attention to problems of refugees.

The specific way of interaction with the readers through the prism of characteristics of the described topic. Replies to Shams Ul-Haq's article are in the structure and fabric of the described narrative in the form of comments of the readers of periodicals in blogs. Thus a holistic picture of perception of the social phenomenon of the homeless in the German society is manifested through the appearance of separate recipient's opinions in mass media. The following somewhat skeptical opinions are the most common: Da wäre es doch am einfachsten, wenn wir erst gar keinen mehr reinlassen. Alles andere ist nur Utopie; Wo bitte hätten wir denn mit einer Million Menschen hin sollen ... in Eigenheime? Sicherlich ist das Leben im Flüchtlingsheim nicht schön, aber diese Menschen flohen doch vor Krieg und Hunger, da sollte man doch froh sein, ein Dach über dem Kopf zu haben; In dieser Situation können wir nur verlieren. Man gibt und hilft so gut man kann - je mehr sie fordern umso mehr. Das logische Problem ist, es kann NIE genug sein. Es ist wie bei einem verwöhnten Kind, also holen sie es sich selber und beginnen uns zu hassen weil sie enttäuscht werden (Welt 05.01.2017) It would have been the easiest not to let any refugees in. Everything else is a Utopia. Where have you seen millions of people ... given their own houses? Surely, living in a refugee camp is difficult, but those people ran from war and hunger, and they must be happy now to have saved their lives. In this situation, we are losers. We help them as much as we can, and they want more. Like spoiled children, they grab much, and then begin to hate those who have disappointed them. - Wem unser Essen, unsere Kultur nicht passen - bitte keiner wird an der Heimreise gehindert (HuffPost Deutschland 01.07.2017). - Those who don't like our food and culture, can go back home, etc. In this case the readers are in a dialogue with the author and narrator, both of the story under discussion and with the characters described on its pages.

\section{Conclusion}

Our analysis of Shams Ul-Haq's empiric material of reports about refugees has shown that in the case of undercover observation in research journalism, transition of the figure of the journalist into diagesis is possible, which leads to the identity of the author, the narrator and one of the characters of the narrative. In the pragmatic sense, it produces synergy of the speech and act interaction through transposition of the journalist/narrator into the milieu of the characters and getting a chance to communicate both with the described actors and with the reader.

Our observation of newspaper narratives with a diagetic position of the author have shown that this method of narration is a special type of sociocultural "evidentiality". In pragmatic sense, it provides an accurate and objective statement of cognitive information in combination with emotional literary details that encourage recipients of mass media texts see not only a real history of a definite person, but also deep ideological, moral and esthetic contents.

The perspectives of further studying of the series of Shams Ul-Haq's diegetic research reports are presumably connected with:

- Analysis of the diegetic narrative in quality and gossip magazines.

- Complex consideration of the opposition "our their" in the discourse about migrants.

- Analysis of the role of secondary acculturation of a journalist in the representation of the "world of our 
people" for the "world of their people" in the Islamic discourse of Europe.

In general, such studies help to identify the communicative and pragmatic effect of mass media narrative about migrants from Islamic countries in the countries of the European Union.

\section{References}

1. G. Genette, Figures III (Seuil, Paris 1972)

2. S. Lanser, The Narrative Act: Point of View in Prose Fiction (Princeton University Press, Princeton, 1981)

3. M.P. Brandes, Text Stylistics (Progress-Tradicija; INFRA-M, Moscow, 2004)

4. K.A. Dolinin, Text Interpretation (KomKniga, Moscow, 2010)

5. E.V. Padutcheva, Semantic Research: Semantics of Time and Aspect in the Russian Language. Semantics of Narrative (Jazyki slavjanskoj kul'tury, Moscow, 2010)

6. E.A. Gontcharova, I.P. Shishkina, Text Interpretation (Vysshaja shkola, Moscow, 2005)

7. W. Schmid, Narratology. Transl. by Starritt, A. (Walter de Gruyter, Berlin, 2010)

8. G. Prince, A Dictionary of Narratology (University of Nebraska Press, Nebraska, 2003)

9. J.A. Teixeira da Silva, A. Al-Khatib, KOME An International Journal of Pure Communication 4(1), 84 (2016)

10. Y. Rodny-Gumede, C. Chasi, African Journalism Studies 37(3), 107(2016)

11. B. Houston, Daedalus 139(2), 45 (2010)

12. B. Avieson, W. McDonald, MIA 163(1), 137 (2017)

13. M.J. Yusha, African Journalism Studies 30(2), 155 (2009)

14. A. Ismaila, M.K. Ahmada, and C.S. Mustaffaa, Procedia - Social and Behavioral Sciences 155, 165 (2014)

15. L.V. Tataru, Narrativ $i$ kul'turnyj kontekst [Narrative and Cultural Context](URSS, Moscow, 2011)

16. S. Tosun, J. Vaid, Applied Psycholinguistics 37(6), 1337 (2016)

17. L. Berlin, A. Prieto-Mendoza, Intercultural Pragmatics 11(3), 389 (2014)

18. E. Oishi, Intercultural Pragmatics 11(3), 437 (2014)

19. E. Reber, Intercultural Pragmatics 11(3), 357 (2014)

20. M. Sbisa, Intercultural Pragmatics 11(3), 463 (2014) 